\title{
Pigment Effects on the Adhesive Strength of Coating Films
}

\author{
Masuo Mizoguchi* and Kenji UeKI** \\ Kashu Co. Ltd.* \\ Institute of Vocational Training**
}

\begin{abstract}
The experiments were carried out to obtain the informations of the effects on the adhesive strength of coating films with some factors such as the kinds of pigment, pigment volume concentration and so on.

The samples were nitrocellulose lacquer, acrylic lacquer and alkyd resin paint. Paints were prepared in various pigment volume concentrations with rutil titanium dioxide and carbon black pigments.

Adhesive strength (Adherometer, ultrasonic wave method and crosshatch test), stressstrain properties and pigment interactions for the respective coating films were determined.

Generally, the adhesive strength of the film increase with pigmentation. However, the cause and the factors which dominate the rate of increase of the adhesive strength are not clear.

From our experimental results, it was found that as the system in which the interaction between pigment and vehicle was large, that is, the system in which the adhesion of vehicle molecule on the surface of the pigment was good, as the increase tendency of the adhesive strength was remarkable.
\end{abstract}

* 8-12-5, Nishiogu, Arakawa-ku, Tokyo.

** 1960, Aihara, Sagamihara-shi, Kanagawa. 


\title{
塗膜の付着強さに及ぼす顔料効果
}

\author{
溝 口 益 男*・植 木 憲 二**
}

要 旨

塗膜の付着に及ぽす顔料効果に知見を得る目的で， NC ラッカー・アクリルラッカー・ アルキド樹脂塗料についてルチル形チタン白・カーボンブラックを用い種々の PVC の塗 膜を調製し，付着強さ・応力〜ヒズミ性・顔料/ビヒクル間相互作用を調べた。

実験結果をまとめると次のようである。

（1）一般に, 付着強さ〜PVC 関係曲線は極大值をもつ曲線を示し，その極大值は顔料 およびビとクルの種類により異なる。

（2）顔料/ビヒクル間相互作用は実験範囲内のビヒクルでは, NC ラッカー・アルキド 樹脂が良好であった。アクリル樹脂はチタン白に対しては良好であったが，カーボン ブラックに対しては良好でなかった。

（3）これらの結果を考察し, 顔料/ビヒクル間相互作用の大きい系活ど付着向上傾向が 大きいようであることを明らかにした。

\section{1. は じめに}

塗膜の付着性に及ぼす顔料効果については古くから報 告されている1 6)。すなわち,一般て顔料容積濃度(PVC) の増大に伴い付着強さは增大するが，付着強さ〜PVC 関係曲線は極大点を示して後下降する。このような極大 点を示すことについては，(1) 顔料補強効果とバインダ 一の付着活性点（極性基）の減少との総合効果，（2）顔 料によるバインダーの無効の極性基の吸着にもとづく極 性基の配列などが考兄られるが，末だ明らかでない。顔 料補強効果 ${ }^{7 ~ 9)}$ や塗膜の内部応力 ${ }^{6,10)}$ が支配因子として あげられる。また，前者に関連して顔料/ビヒクル間の 相互作用も重要な因子と考光られる ${ }^{11)}$ が, 付着強さと顔 料/ビヒクル間相互作用とを直接関係づけた報告はない ようである。

筆者らはバインダーとして NC/DBP・熱可塑性アク リル樹脂・アルキド樹脂を選び, 典型的顔料であるルチ ル形チタン白 $\left(\mathrm{R}-\mathrm{TiO}_{2}\right.$ と略す）执よびカーボンブラッ

昭和 48.6.29 受理

* カシュー(株)

東京都荒川区西尾久 8-12-5

** 職業訓練大学校

神奈川県相模原市相原 1960
ク（CB と略す）を使用した PVC の一連に異なるエナ メルを調製して，付着強さに及ぼす PVC の影響を測定 した。同時に, 塗膜の応力〜ヒズミ性, (顔料補強効果) ならびに吸水率 (顔料/ビヒクル間相互作用) の測定も行 なって，付着向上の原因を追求した。

そして興味深い結果を得たので報告する。

\section{2. 試料および試験法}

\section{1 試 料}

（1） NC ラッカー……市販の $1 / 2$ 秒 NC と DBP（不 揮発分中 $40 \%$ 添加）からなる透明ラッカーを調製し, 市販の $\mathrm{R}-\mathrm{TiO}_{2}(\mathrm{R}-820)$ 特よび $\mathrm{CB}$ (ネオスペクトラ AG）とそれぞれ練磨してエナメルを調製した。混合溶 剂の組成は次の通り。

$\begin{array}{lc}\text { 酹酸エチル } & 25 \% \\ \text { 酢酸ブチル } & 25 \\ \text { 䣬酸セロリルブ } & 5 \\ \text { トルオール } & 45\end{array}$

（2） アクリルラッカー……市販の熱可塑性樹脂（ア クリロイド B-66, デュポン社製）にDBP を固形分とし てそれぞれ $3 \%$ 特よび $10 \%$ 混合した 2 種の透明ラッカ 一をつくり，それぞれ $\mathrm{R}-\mathrm{TiO}_{2}$ 执よび $\mathrm{CB}$ と練磨してエ ナメルを調製した。溶㓮組成は次の通り。

$\overline{2[12]}$ 


$\begin{array}{ll}\text { MIBK } & 30 \% \\ \text { トルオール } & 70\end{array}$

（3）アルキド樹脂塗料……市販の中油性あまに油変

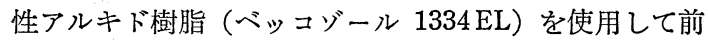
項と同様にエナメルを調製した。溶剤は MS，乾燥剤は 樹脂固形分に対し $6 \%$ ナフテン酸コバルト $1 \%+24 \%$ ナ フテン酸鉛 $1 \%$ を添加した。

\section{2 試験片の調製と試験法}

（1）付着強さ試験……軟鋼板 $(150 \times 70 \times 0.5 \mathrm{~mm})$ を \#320 研磨紙で研磨し溶剂で脱脂した後, 直ちに各試料 を吹付塗装した。室内で 7 日間乾燥し,さらに $60 \sim 70^{\circ} \mathrm{C}$ /48 時間強制乾燥してこれを付着試験用試験片とした。 平均膜厚 $45 \pm 5 \mu$ 。

付着強さ測定にはアドへロメーター・ゴバン目・超音 波付着試験機を用いた。アドへロメーター ${ }^{12)}$ では各試片 につき 5 回測定し, その平均值を測定值とした。ゴバン 目試験 ${ }^{13)}$ では各試片につき 5 回測定し, 10 点法で評価

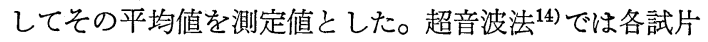
につき 5 回測定し，ハク離までの平均秒数で表示した。 測定水温は $10 \pm 1^{\circ} \mathrm{C} て ゙$ て行なった。

（2）応力〜ヒズミ性測定……各試料をブリキ板 $(100$ $\times 150 \mathrm{~mm}$ ) に吹付塗装し，（1 項と同様な条件で十分 乾燥した。アマルガム法によって $10 \times 150 \mathrm{~mm}$ の遊離膜 をつくり，これを応力〜ヒズミ測定用試験片とした。平 均膜厚 $80 \mu$ 。

Instron 形万能材料試験機を用い $10 \mathrm{~mm} /$ 分で引張試 験を行なった。5 回の值を平均して測定值とした。測定 温湿度 $16 \sim 19^{\circ} \mathrm{C} / 60 \sim 75 \% \mathrm{RH}_{0}$

（3）塗膜吸水率の測定……（2）と同様に調製した $25 \times 25 \mathrm{~mm}$ (平均膜厚 $80 \mu$ ) の遊離膜を吸水率測定用試 験片とした。

試験片を 24 時間水に浸セキした。この条件で平衡膨 潤度に達した。塗膜の吸水率 $Q$ は次式から算出した。

$$
Q=\frac{W_{S}-W_{0}}{W_{0}} \times 100(\%)
$$

$W_{S}:$ 浸セキ後の塗膜重量

$W_{0}:$ 漫セキ塗膜を乾燥した後の重量

\section{3. 結果亡考察}

\section{1 塗膜の付着強さ}

図-1，2 にそれぞれアドへロメータ一付着強さに及注 す $\mathrm{R}-\mathrm{TiO}_{2}$ 特よび $\mathrm{CB}$ の $\mathrm{PVC}$ の影響についての測定結 果を示す。図-3，4 に同一試料についての超音波付着試 験機による結果を示す。ゴパン目試験法による結果は, $\mathrm{R}-\mathrm{TiO}_{2}, \mathrm{CB}$ とも，アルキド樹脂塗料ではすべて 10 点

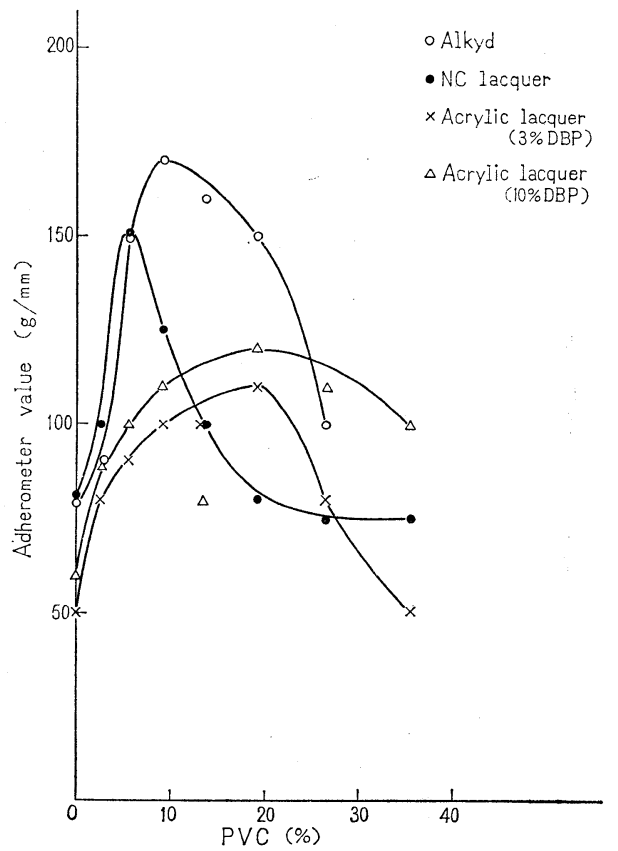

Fig. 1. Dependence of PVC on the adherometer value, $\mathrm{R}-\mathrm{TiO}_{2}$-coating films

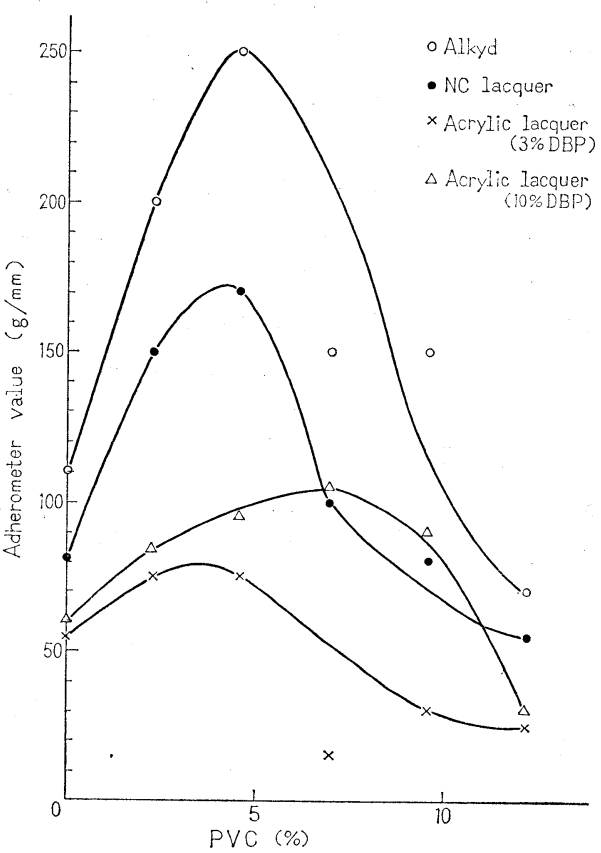

Fig. 2. Dependence of PVC on the adherometer value, $\mathrm{CB}$-coating films

であったが， NC ラッカー・アクリルラッカーではすべ て0点を示したので図示を省略した。このようにゴバン 目試験法は付着良否の極端な差異は評価できるが，付着 


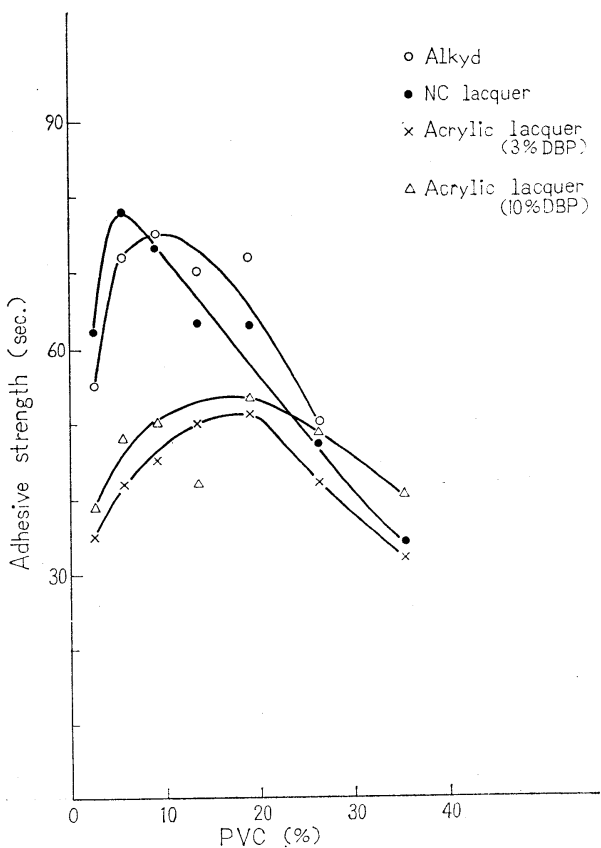

Fig. 3. Dependence of $\mathrm{PVC}$ on the adhesive strength by ultrasonic wave method, $\mathrm{R}-\mathrm{TiO}_{2}$-coating films

強さの定量には不適当であると考えられる。

各種塗料の付着強さの極大值とこれに対応する PVC をまとめて表-1 に示す。

付着試験法が違えば当然その測定機構も異なるが，極 大付着強さを与える $\mathrm{PVC}, \mathrm{PVC}_{\max }$. や塗料の種類によ る順位などについて，アドへロメーターと超音波法では 比較的よく一致した結果を示した。ただ，アクリルラッ カー黒エナメルのみが超音波法で極端に悪い結果を示し た。この理由は明らかでない。

\section{2 塗膜の応力〜ヒズミ特性}

繁雑をさけるために各試験片の応力〜ヒズミ曲線の図

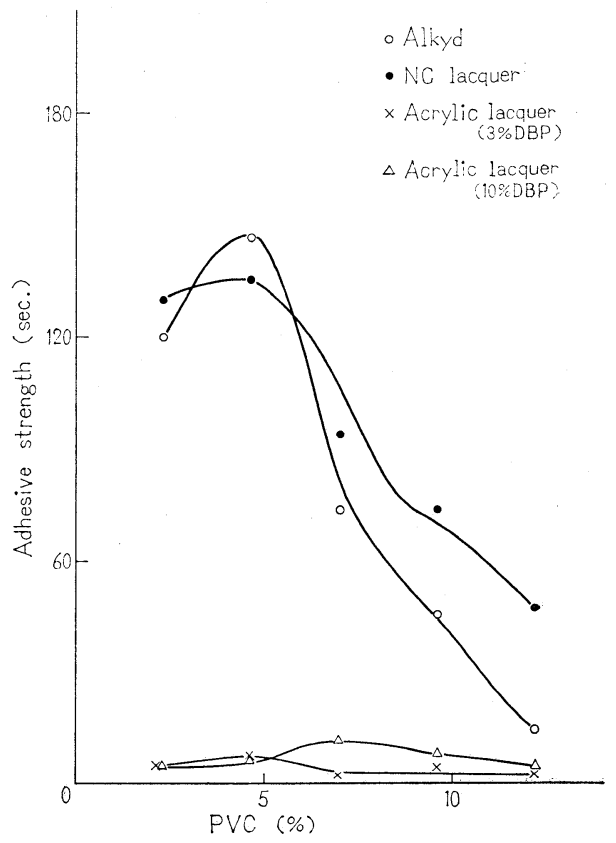

Fig. 4. Dependence of PVC on the adhesive strength ultrasonic wave method, CBcoating films

示を省略するが, いずれの系に和いても PVC の増大に 伴い加成的に弾性率・抗張力は増加を示し破壊伸びは減 少した。

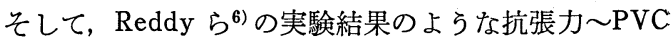
関係曲線が一定 PVC で極大を示す結果は得られなかっ た。

\section{3 塗膜の吸水率}

一般に顔料は水または各種溶剂に膨潤しない用体と考 えられるから, 塗膜の吸水率はビヒクルにのみ依存する と考えてよい。しかし，実際には顔料の種類や PVC に よって塗膜の吸水挙動は著しく変わる。

Table 1. Experimental results on adhesion

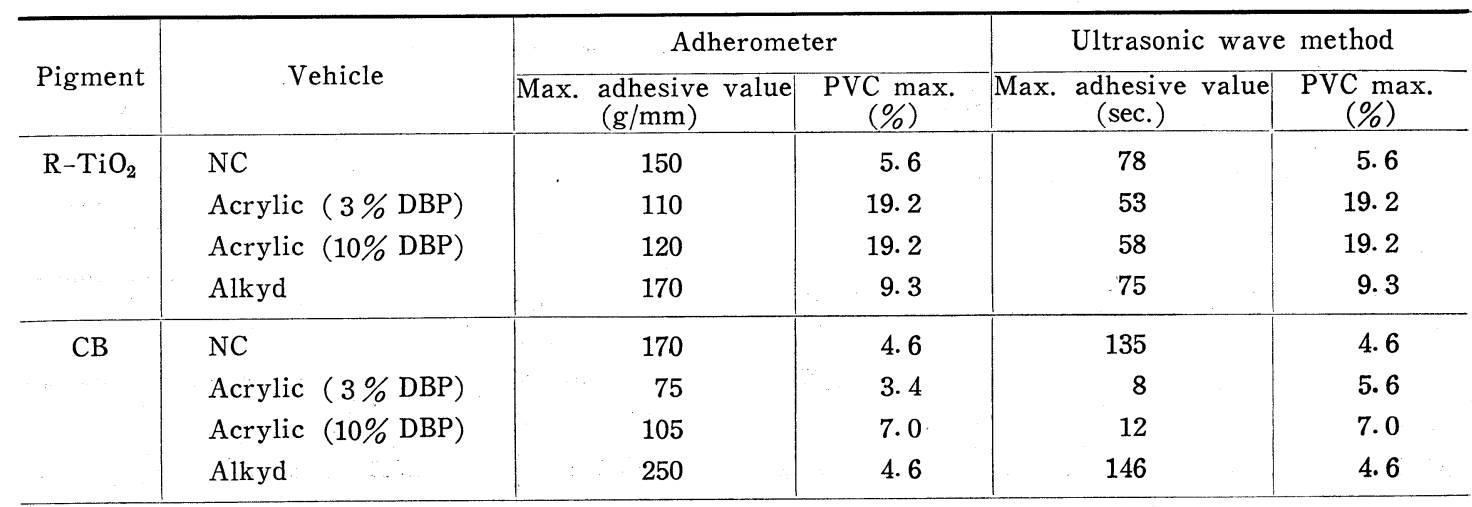




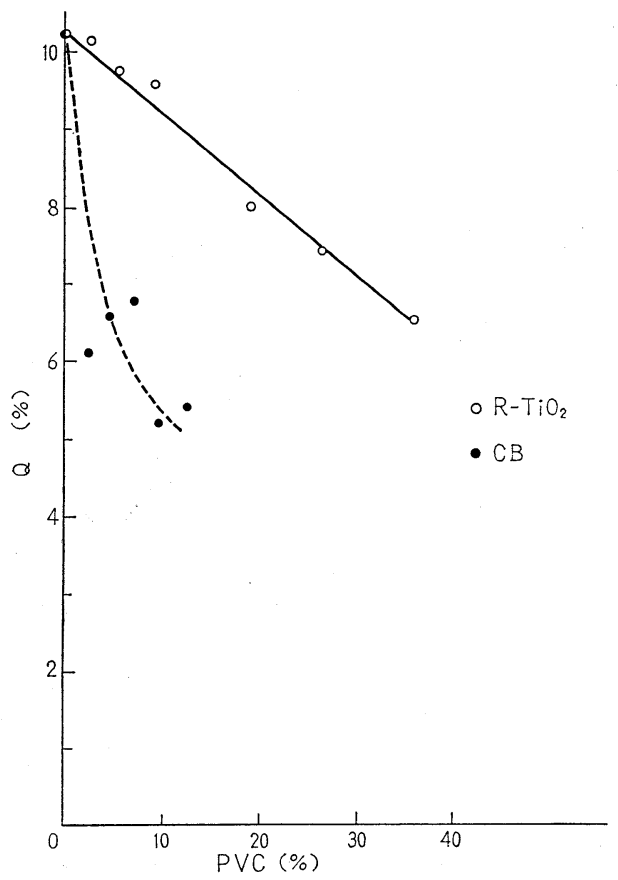

Fig. 5. Relations between the water absorption of NC/DBP films and their PVC

$(Q=$ water absorption based on vehicle content)

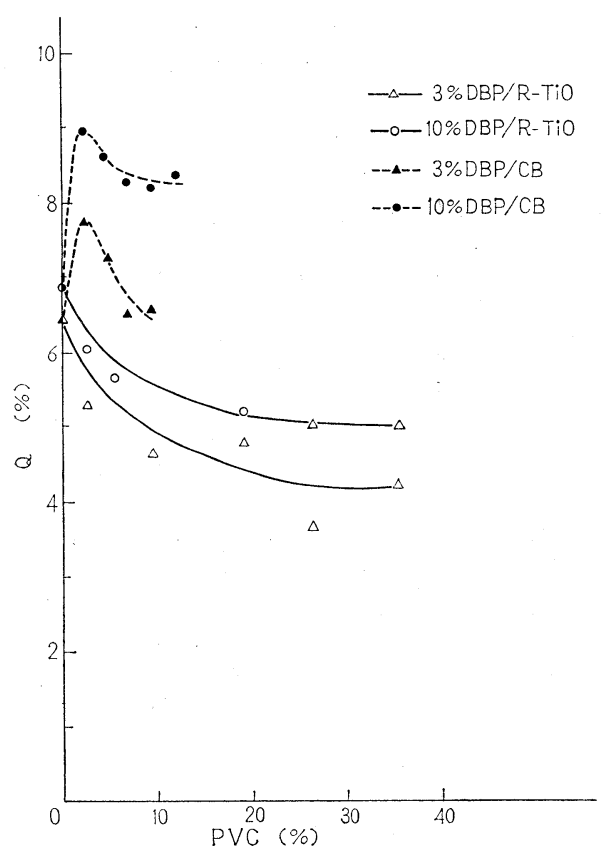

Fig. 6. Relations between the water absorption of acrylic films and their PVC

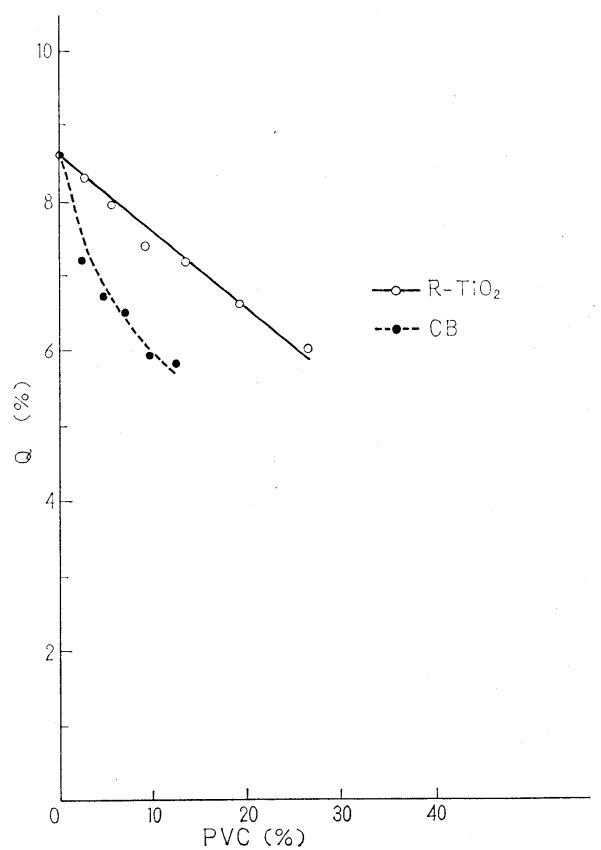

Fig. 7. Relations between the water absorption of alkyd films and their PVC

Funke15 17) は顔料/ビヒクル間相互作用の尺度として 塗膜の透水率または吸水率〜PVC 関係曲線を用いるこ とを提唱した。すなわち, 顔料/ビとクル間が完全接着 である系では PVC の増大に伴い吸水率Qは一定または 低下する。反対に顔料/ビヒクル間が不完全接着であれ ば，Qは上昇し極大点を示すことを明らかにした。

図-5〜7 に各試片の $Q \sim \mathrm{PVC}$ 関係の測定結果を示す。 $\mathrm{NC}$ ラッカーおよびアルキド樹脂塗膜では, $\mathrm{R}-\mathrm{TiO}_{2}$, $\mathrm{CB}$ 系ともに, PVC の増大にともない $Q$ 値は低下した。 しかも， $\mathrm{R}-\mathrm{TiO}_{2}$ 系に比らべ $\mathrm{CB}$ 系の方がこの低下の傾 向が著しい。これら 2 種の顔料は粒子の形状・大きさ・ 分布状態その他表面状態などが著しく違う種類であるか ら, 曲線の低下傾向即顔料/ビヒクル間相互作用の大小 と断定することは困難である。しかし，この両系では $\mathrm{R}-\mathrm{TiO}_{2}$ に比べ $\mathrm{CB}$ の方が完全接着に比較的近いと考え てよからら。

アクリルラッカー系では, DBP の混合割合に関係な く, 顔料粒子表面とビヒクル間が $\mathrm{R}-\mathrm{TiO}_{2}$ では完全接 着, $\mathrm{CB}$ では不完全接着であることを明瞭に示す。

付着強さ〜PVC 関係曲線が極大点を示す理由は PVC の増大に伴い塗膜が強じんになること（顔料補強効果） と付着活性点を有する塗膜形成要素の配合比が低下する ための活性点の減少との総合効果として付着強さが示さ れることによる。もちろん, 塗膜の内部応力や応力緩和 
Table 2. Relationship between adhesive value and pig./veh. interaction

\begin{tabular}{l|c|c|c|c|c|c|c|c}
\hline \multicolumn{1}{c|}{ Pigment } & \multicolumn{4}{c|}{$\mathrm{R}-\mathrm{TiO}_{2}$} & \multicolumn{4}{c}{$\mathrm{C}$ B } \\
\cline { 2 - 9 } Vehicle & $\begin{array}{c}\text { Max. } \\
\text { adhesive } \\
\text { value } \\
(8 \mathrm{~mm})\end{array}$ & $\begin{array}{c}\text { PVC max. } \\
(\%)\end{array}$ & Ratio* & $\begin{array}{c}\text { Pig./Veh. } \\
\text { interaction }\end{array}$ & $\begin{array}{c}\text { Max. } \\
\text { adhesive } \\
\text { value } \\
(\mathrm{g} / \mathrm{mm})\end{array}$ & $\begin{array}{c}\text { PVC max. } \\
(\%)\end{array}$ & Ratio* & $\begin{array}{c}\text { Pig./Veh. } \\
\text { interaction }\end{array}$ \\
\hline NC & 150 & 5.6 & 1.9 & $\bigcirc$ & 170 & 4.6 & 2.1 & $(0)$ \\
Acrylic (3\% DBP) & 110 & 19.2 & 2.2 & $\bigcirc$ & 73 & 3.4 & 1.5 & $\times$ \\
Acrylic (10\% DBP) & 120 & 19.2 & 2.0 & $\bigcirc$ & 105 & 7.0 & 1.8 & $\times$ \\
Alkyd & 170 & 9.3 & 1.9 & $\bigcirc$ & 250 & 4.6 & 2.8 & $(0)$ \\
\hline
\end{tabular}

* Adhesive value at PVC max./Adhesive value of clear film.

の難易も重要な要因である。したがって，軟質の塗膜形 成要素からなる塗膜では, 顔料補強効果が特に顕著に現 われる。また，付着試験機の測定機構にもよるが，実用 塗膜の付着強さは塗膜/被塗物界面に特ける純接着破壊 強さばかりではなく, 塗膜バルクの強さも付着強さに加 味されて測定されることが多くの人々によって明らかに されている18)。

また，顔料自体は付着能力をもたないが，適度のPVC は塗膜形成要素の無用な付着活性点 (van der Waals 力 による分子内環化や隣接ポリマー分子との引張り合いに 消費される）を顔料表面に吸着させるために，かえって 付着強さの向上に寄与する。この現象には限度があり, 過度の PVC の増大は当然付着強さの低下をまねく。

われわれの実験結果について，付着強さ・その向上比 $\left(\mathrm{PVC}_{\mathrm{max}}\right.$. の付着強さ/透明塗膜の付着強さ)なとと吸 水率測定から得られた顔料/ビヒクル間相互作用に関す る知見とを対比して検討すると，きわめて興味深い。こ れらの結果をまとめて表-2 に示す。

いずれの試料についても顔料/ビヒクル間相互作用の 大さい系ほど, 顔料添加による付着強さの増加割合が著 しいことが認められる。

塗膜の応力〜ヒズミ測定結果のみからは，顔料による 付着向上の優劣は判定できないが, 顔料/ビヒクル間相互 作用を考慮すれば，より合理的にこれらの現象を説明す ることができよう。すなわち，相互作用の大きいエナメ ル系ほど付着向上に対する寄与率が高い。

\section{4. 終りに}

塗膜の付着に及ぼす顔料の効果についてはすでにいく つかの報告がある。しかし，どのような種類の顔料が最 も付着向上に有効であるかなどについては明らかでな w。

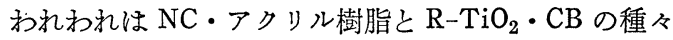
の組合わせ系についての実験結果に基づき, 顔料/ビヒ クル間相互作用が大きい組合わせほど付着向上に有効で あろらと大胆に仮定した。しかしこの仮定の当否を確認 するためには，さらに広範囲の系についての実験結果な らびに理論的裏付けが必要である。今後さらに検討する 予定である。

\section{文献}

1) Epstain : Epoxybased Adhesives, Sep. (1956)

2) Permoda, Carrick : Official Digest., 27, 653 (1955)

3）植木憲二・高橋誠一：金表研究発表会（1962）

4）植木憲二：色材，36，557 (1963)

5）佐藤弘三：色材，39，616（1966）

6) J. N. Reddy, R. V. Rao, P. S. Sampathkumaran, M. A. Sivasamban: J. Paint Tech., 44, 70 (1972)

7）井上幸彦：高分子， 7，388（1958）

8）植木憲二：色材， 36, 557 (1962)

9）久下靖征 -中道敏彦・藤井二十六・植木憲二 : 色 材, 42，495 (1969)

10）牛尼清治・中根新一・植木憲二：色材， 44, 263 (1971)

11）植木憲二：表面, 41, 386 (1968)

12）植木憲二：表面，7，592（1969）

13）植木憲二 : 表面, 7, 589 (1969)

14）早船義雄・渡辺秀則・植木憲二：色材， 45, 236 (1972)

15) W. Funke : J. Oil Col. Chem. Assoc., 50, 942 (1967)

16) W. Funke : J. Oil Col. Chem. Assoc., 54, 230 (1971)

17) W. Funke, U. Zorll, B. G. K. Murthy : J. Paint Tech., 41, 210 (1969)

18) W. K. Asbeck : 9 th FATIPEC Congress Book, p-78 (1968) 